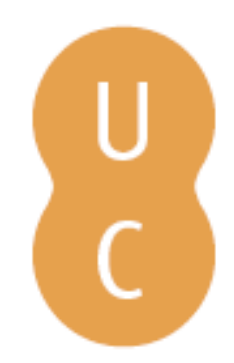

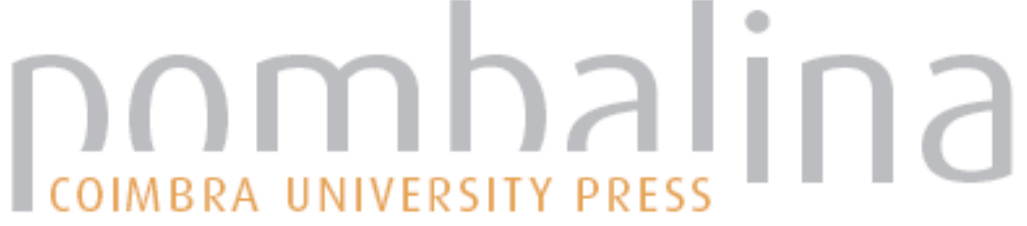

\section{Caminhos da retomada do Ceticismo Antigo no Pensamento Moderno}

\author{
Autor(es): $\quad$ Marcondes, Danilo \\ Publicado por: Imprensa da Universidade de Coimbra; Annablume \\ URL \\ URI:http://hdl.handle.net/10316.2/40871 \\ DOI: $\quad$ DOI:https://doi.org/10.14195/978-989-26-1288-1_11 \\ Accessed : $\quad$ 26-Apr-2023 13:17:41
}

A navegação consulta e descarregamento dos títulos inseridos nas Bibliotecas Digitais UC Digitalis, UC Pombalina e UC Impactum, pressupõem a aceitação plena e sem reservas dos Termos e Condições de Uso destas Bibliotecas Digitais, disponíveis em https://digitalis.uc.pt/pt-pt/termos.

Conforme exposto nos referidos Termos e Condições de Uso, o descarregamento de títulos de acesso restrito requer uma licença válida de autorização devendo o utilizador aceder ao(s) documento(s) a partir de um endereço de IP da instituição detentora da supramencionada licença.

Ao utilizador é apenas permitido o descarregamento para uso pessoal, pelo que o emprego do(s) título(s) descarregado(s) para outro fim, designadamente comercial, carece de autorização do respetivo autor ou editor da obra.

Na medida em que todas as obras da UC Digitalis se encontram protegidas pelo Código do Direito de Autor e Direitos Conexos e demais legislação aplicável, toda a cópia, parcial ou total, deste documento, nos casos em que é legalmente admitida, deverá conter ou fazer-se acompanhar por este aviso. 


\section{Cosmópolis}

\section{mobilidades culturais às origens do pensamento antigo}

Gabriele Cornelli, Maria do Céu Fialho e Delfim Leão

\section{(coords.)}

IMPRENSA DA UNIVERSIDADE DE COIMBRA 


\title{
Caminhos da retomada do Ceticismo Antigo no Pensamento Moderno
}

\author{
(Trajectories of the rediscovery of Ancient Scepticism in Modern Thought)
}

\author{
Danilo Marcondes (danilo@puc-rio.br) \\ Pontifícia Universidade Católica do Rio de Janeiro/Universidade Federal Fluminense
}

It is my contention that scepticism plays a special and different role in the period extending from the religious quarrels leading to the Reformation up to the development of modern metaphysical systems in the seventeenth century. Richard Popkin, The history of scepticism from Savonarola to Bayle

Resumo: Richard Popkin mostrou que a retomada do ceticismo antigo no período moderno levou à formulação de um ceticismo moderno, distinto do ceticismo antigo. Uma dessas características em seu período inicial foi o que Popkin denominou "ceticismo fideísta", consistindo no uso de argumentos céticos para problematizar os limites da razão, abrindo assim caminho para a fé. Essa discussão é particularmente importante no contexto da Reforma e da Contra-Reforma. Alguns historiadores da filosofia contestam porém a centralidade que Popkin atribui ao ceticismo nesse contexto e questionam a própria concepção de um ceticismo fideísta. Recorrendo ao humanista Guillaume Budé procuro mostrar que este pensador defende um tipo de fideísmo, atacando o recurso aos clássicos, inclusive ao ceticismo e ao estoicismo. Pode-se ver aí a influência de pensadores cristãos do Helenismo, os apologistas e representantes da patrística do período ante-nicêncio, que, relidos no início do período moderno, permitem um paralelo entre as controvérsias do início do Cristianismo e as do século XVI. Além disso, os textos dos apologistas e da patrística são também fonte de transmissão da filosofia cética através de referências a estes filósofos. Proponho assim uma leitura que favorece a interpretação de Popkin sobre o início do ceticismo moderno.

Palavras-chave: Ceticismo antigo e moderno; Popkin; Patrística

Aвstract: According to Richard Popkin, the rediscovery of ancient philosophy in modern thought opened the way to a new form of scepticism which he considers characteristic of modernity, sceptical fideism. This has been contested by a number of historians of philosophy. I turn to a neglected author, the humanist Guillaume Budé, who in his later work criticized the humanistic revival of the Classics as a threat to Christianity. Budé refers to the transition from Hellenism to Christian thought in Late Antiquity as importing philosophical questions into religious thought and thus provoking a conflict of doctrines inherited from philosophy. This argument allows us to show a parallel between early Christian thought and the religious conflicts in the sixteenth century, as well as to consider the revival of Patristic thought in the Renaissance as an important source for the knowledge of Classical philosophers, among them Pyrrhonians and Academics.

Keywords: Ancient and modern scepticism; Popkin; Patristic 
A interpretação da formação do pensamento moderno foi revolucionada na década de sessenta do século XX por novas e originais hipóteses formuladas por historiadores da filosofia como Richard Popkin (2003), Paul Oskar Kristeller (1979) e Charles B. Schmitt (1983). Popkin e Schmitt, sobretudo, mostraram que a retomada do ceticismo antigo no contexto do humanismo renascentista teve um impacto sobre a Modernidade até então pouco reconhecido.

Popkin (1979) em "O ressurgimento do ceticismo grego no século XVI" (segundo capítulo de História do Ceticismo de Erasmo a Spinoza) e Schmitt (1983) em "The rediscovery of ancient skepticism in modern times", significativamente textos com títulos muito próximos, apontam sobretudo para o impacto da releitura de obras clássicas principalmente de Sexto Empírico (1979), Cícero (1976) e Diógenes Laércio (1989). Popkin (op. cit.) analisa a recepção dessas obras no contexto do que denomina "crise intelectual da Reforma" (título do primeiro capítulo do livro supracitado), enfatizando as controvérsias teológicas como pano de fundo dessa releitura, o que, segundo sua interpretação, acaba por dar origem a um novo tipo de ceticismo, desconhecido na Antiguidade, consistindo no uso de argumentos céticos, derivados dos filósofos antigos, acadêmicos e pirrônicos, para a discussão de questões religiosas. Isso culmina efetivamente, ainda segundo essa interpretação, na formulação de uma nova problemática cética e de um novo tipo de ceticismo, que denomina de "ceticismo fideísta". Este é para Popkin (op. cit.) um dos principais caminhos da retomada do ceticismo antigo na Modernidade, levando à formulação de um ceticismo moderno, ou melhor, de uma versão moderna do ceticismo, não encontrada no Helenismo. Pretendo discutir aqui em que sentido e em que medida isso realmente se dá.

Mostra também como esse caminho foi aberto a partir da controvérsia, central para a Reforma, em torno da proposta por Lutero da "regra da fé" como critério de solução para disputas quanto à interpretação das Escrituras e também quanto a outras questões teológicas, ou doutrinárias, da época ${ }^{2}$. Segundo Popkin isso teria levado à retomada de um dos principais problemas do ceticismo antigo, "o problema do critério da verdade", cuja resposta seria dada neste momento pelo recurso à fé como a única forma de superação do conflito.

De acordo com essa análise o problema cético do critério e o uso dos argumentos céticos na Modernidade teriam começado no contexto desta controvérsia de caráter teológico e apenas em um segundo momento se desenvolvido como questão epistemológica. Popkin chega mesmo a dizer que Descartes fez a "Reforma na filosofia" ${ }^{3}$.

\footnotetext{
${ }^{1}$ Em Miles Burnyeat 1983: 225-252.

2 Popkin 2003, capítulo 1. Ver, por exemplo, a controvérsia entre Erasmo e Lutero a propósito do livre arbítrio. Ver Winter 2005.

${ }^{3}$ Popkin, 2003, capítulos 9 e 10.
} 
Contudo, mais recentemente historiadores das ideias como Quentin Skinner (2002) e especialistas na filosofia dos séculos XVI e XVII como Françoise Caujolle-Zaslawski (1977), Emmanuel Naya (2009) e Sylvia Giocanti (1998) têm questionado esta tese por diferentes motivos.

Skinner (op. cit.) diverge da relevância atribuída ao ceticismo neste período, considerando que a argumentação dialética que Popkin (op. cit.) e Schmitt (op. cit.) identificam como evidência do recurso ao ceticismo pode ser interpretada simplesmente como característica mais geral da retórica antiga revivida e reelaborada no Renascimento. Não haveria assim nenhuma especificidade na recepção do ceticismo antigo nesse contexto, este seria apenas uma das várias correntes filosóficas do Helenismo então retomadas e as obras destes filósofos, como Sexto Empírico, não teriam trazido nenhuma contribuição em especial. As referências a autores céticos não teriam sido, segundo Skinner, particularmente importantes:

"My hypothesis is thus that the anxieties expressed by seventeenth-century philosophers about moral ambiguity stem less from the rise of Pyrrhonism than from the Renaissance revival of the classical art of eloquence.

This [i.e.Popkin's hypothesis] has certainly proved a fruitful hypothesis, but it has, I think led to an overemphasis on this particular strand of thought. Such writers as Hobbes, Wilkins and Locke were not merely or even primarily responding to a set of epistemological arguments. Rather they were reacting against the entire rhetorical culture of humanism within which the vogue for scepticism had developed. Nor were they mainly concerned with the technical arguments put forward by the sceptics, whether of a Pyrrhonian or an Academic stamp. Rather they were seeking to overcome a more general sceptical outlook encouraged by the empahsis placed by the humanists on the Ars rhetorica, with its characteristic insistence that there will always be two sides to any question, and thus that in moral reasoning it will always be possible to construct a plausible argument in utramque partem, on either side of the case".

Pode-se contra-argumentar porém, que há uma diferença central entre por um lado a retomada da retórica antiga e seu uso sobretudo no discurso político, analisado por Skinner em várias de suas obras ${ }^{5}$, e por outro lado o uso de argumentos céticos como os tropos de Enesidemo ${ }^{6}$, por exemplo, que têm um objetivo epistêmico, ou seja, levam ao questionamento de pretensões a conhecimento, inclusive teológico, como encontrados na escolástica do final da Idade Média. Os tropos são efetivamente retomados no pensamento moderno. O

\footnotetext{
${ }^{4}$ Skinner 2002: 265-266.

${ }^{5}$ O texto clássico é Skinner 1997.

${ }^{6}$ Annas \& Barnes: 1985
} 
destaque dado à existência de edições em separado do capítulo sobre $\mathrm{Pirro}^{7}, A$ vida de Pirro, em Diógenes Laércio evidencia o grande interesse pela filosofia cética no início da Modernidade para além do campo da retórica e do uso de argumentos in utramque partem. O uso desses tropos na Apologia de Raimond Sebond de Michel de Montaigne é um dos principais exemplos disso. E a Apologia foi um texto de grande influência na Modernidade. Outro exemplo importante nesse novo contexto se encontra, um pouco mais tarde, no Dictionnaire historique et critique (1696) de Pierre Bayle, sobretudo em sua discussão sobre o ceticismo no verbete "Pyrrhon".

Skinner estabelece, contudo, uma distinção que me parece importante e com a qual tendo a concordar, entre a influência mais direta da retomada de textos céticos, Pirrônicos ou Acadêmicos, e o que chama de "a more general sceptical outlook", resultando de um contexto de conflito de doutrinas e de ausência de critério de solução deste conflito. É em relação a este contex to histórico que a retomada do ceticismo antigo no período moderno deve ser interpretada.

Em outra direção, Caujolle-Zaslawsky (1977), Giocanti (1998) e Naya (2009) veem uma supervalorização do papel do ceticismo na interpretação que Popkin (op. cit.) apresenta especificamente do contexto do protestantismo e das controvérsias religiosas do século XVI. Para esses autores, nem a retomada dos textos céticos alimenta significativamente a controvérsia religiosa, nem a controvérsia religiosa recorre especialmente aos céticos gregos.

Caujolle-Zaslawsy (1977) aponta que a problemática religiosa não se encontra no ceticismo antigo e que nenhum filósofo cético antigo jamais foi acusado de ateísmo, embora outros o tenham sido como Diágoras, Pródicos e Anaxágoras. Conserva-se mesmo a tradição relatada por Diógenes Laércio de que Pirro teria exercido a função de sacerdote em Élis, possivelmente do templo de Hades. Como a questão religiosa enquanto objeto de controvérsia está ausente deste contexto, não se encontra tampouco nenhuma versão de ceticismo fideísta, nem do ataque à razão como um caminho para a fé, ou outro tipo de experiência transcendente. Essa problemática sequer se colocaria no contexto do ceticismo antigo. Segundo sua análise as posições encontradas nos séculos XVI e XVII que relacionam o ceticismo seja com o ateísmo, seja com o fideísmo são incoerentes com o ceticismo pirrônico tal como apresentado por Sexto Empírico e vão contra a postulação pelos pirrônicos da suspensão do juízo diante de posições opostas. Ao contrário da interpretação de Popkin, o fideísmo moderno não poderia assim ter sua origem no Pirronismo. $\mathrm{O}$ argumento de Popkin (op. cit., cap.1), contudo, não depende da fidelidade interpretativa do assim chamado

\footnotetext{
${ }^{7} \mathrm{Na}$ própria edição de H. Etienne das Hipotiposes Pirrônicas de Sexto Empírico. Ver Diógenes Laércio 1989: 267-279, cuja primeira edição latina é de 1533. Ver também Floridi 2002: 73.
}

${ }^{8}$ Bayle 1994: 62-65; E. Naya 2009: 15-32; Blackwell: 1993. 
"ceticismo fideísta" ao Pirronismo. Trata-se antes de uma versão moderna do ceticismo, precisamente não encontrada na filosofia cética antiga, mas resultando da apropriação dos argumentos céticos sobre os limites da razão em defesa da fé como superação desses limites. Isso se dá no contexto de disputas religiosas provocadas pela Reforma e pela Contra-Reforma.

Giocanti (1998) e Naya (2009) também consideram que o ceticismo não tem o peso que Popkin (op. cit.) lhe atribui neste período da Reforma e da Contra Reforma. Sua influência no século XVII corresponde à retomada de textos clássicos desta corrente como as edições de Sexto Empírico em latim realizadas apenas na segunda metade do século XVI. Colocam assim em questão o próprio sentido de um "ceticismo fideísta" característico da Modernidade e ausente do contexto antigo. Giocanti (1998) questiona diretamente a articulação proposta por Popkin entre religião e ceticismo assim como sua caracterização do ceticismo fideísta moderno, sobretudo quanto à interpretação da Apologia de Raimond Sebond de Montaigne9. Contrariamente a Popkin, não vê nesta obra evidências da utilização de argumentos céticos como colocando em xeque a razão e com isso abrindo caminho para a experiência da fé.

Proponho examinar um pensador, hoje um tanto obscuro, mas muito influente em sua época, que pode nos fornecer uma nova perspectiva sobre esta controvérsia. Trata-se do grande humanista francês Guillaume Budé (1467-1540) que em uma de suas últimas obras, De transitu Hellenismi ad Christianismum libri tres (1535/1993) foi um dos primeiros a discutir criticamente a retomada do pensamento antigo e sua influência no Cristianismo do Renascimento e do início da modernidade. Levantando a questão do impacto e das consequências desta "transferência cultural" ${ }^{10}$, o "transitu" do título, Budé preocupa-se sobretudo em defender a superioridade do Cristianismo diante do que receia ser o ressurgimento de um pensamento pagão por influência desta retomada. A retomada do pensamento filosófico antigo pelos humanistas significaria que suas controvérsias seriam trazidas para dentro do Cristianismo e se tornariam uma ameaça à sua unidade.

Pode parecer surpreendente que um grande humanista como Budé, um dos principais responsáveis pela difusão dos clássicos na França do século XVI, conselheiro de Francisco I e responsável pela biblioteca do rei em Fontaineble$\mathrm{au}$, origem da Biblioteca Nacional, e inspirador do Collège de France, tenha condenado ele próprio nessa sua última obra o Humanismo que anteriormente propagara.

No quadro de meu projeto atual de pesquisa sobre os vários caminhos da retomada do ceticismo antigo no período moderno, pretendo defender aqui a

\footnotetext{
${ }^{9}$ Ver também Zerba 2012.

${ }^{10}$ Recorro aqui ao conceito inicialmente proposto por E.T. Hall: 1976.
} 
posição de Popkin (op. cit.) e Schmitt (op. cit.) de que efetivamente o ceticismo antigo teve um papel preponderante neste processo e, em sua versão moderna, produziu inclusive novas formas de ceticismo, dentre elas o ceticismo fideísta. A crítica de Budé ao Humanismo parece apontar para este caminho e tem um forte parentesco com os argumentos em defesa da fé contra a filosofia grega encontrados no início do Cristianismo. Pretendo indicar assim que o que Popkin (op. cit.) denomina de "crise intelectual da Reforma" tem um precedente importante nas controvérsias religiosas dos dois primeiros séculos do Cristianismo, período em que se apelou igualmente para a filosofia grega pagã, inclusive o ceticismo, na formulação de doutrinas e no combate às heresias. Sendo assim, as obras dos apologistas e da Patrística, às quais se recorreu nesse contexto de controvérsia religiosa, também contribuíram para a retomada do ceticismo antigo no período moderno e para a formulação de uma nova versão do fideísmo já encontrado no início do Cristianismo ${ }^{11}$. Os apologistas embora historicamente estejam incluídos na Patrística se distinguem desta por terem escrito defesas do Cristianismo nos três primeiros séculos, algumas delas dirigidas a imperadores romanos. Destacam-se São Justino e Atenágoras, ambos do século II. Dentre os filósofos da Patrística são particularmente importantes Orígenes e São Clemente, cujo Stromateis, uma antologia de textos de filósofos gregos, é uma fonte importante dos tropos de Enesidemo.

Tertuliano (c. 155-222), teólogo latino que se contrapõe ao recurso à filosofia grega, chega já a empregar inclusive a usar a expressão "regula fidei” ${ }^{2}$ a que Lutero recorre a propósito das controvérsias sobre a interpretação das Escrituras (Popkin, op. cit.)

Para desenvolver esta análise proponho uma distinção na linha de Skinner (acima) entre (1) um "sentido amplo de ceticismo" como consequência de um contexto de conflito e de um conjunto de problemas e de estratégias argumentativas derivados dos filósofos céticos antigos, e (2) a filosofia cética, ou seja, a corrente filosófica representada na Antiguidade pelos filósofos Acadêmicos e Pirrônicos.

A modernidade teria sido influenciada por um lado pelo ceticismo em um sentido amplo e por outro lado, pelos Acadêmicos e Pirrônicos. A presença de questões céticas, ou seja do conflito entre doutrinas e da ausência de um critério argumentativo, racional, para defender uma das posições, constatando assim um impasse (aporia), não depende apenas da leitura efetiva de textos de filósofos considerados céticos, mas caracteriza uma problemática filosófica mais ampla e uma atitude diante de problemas filosóficos, ou teóricos, de modo geral. A 2012

${ }^{11}$ Sobre este contexto em relação ao humanismo renascentista ver Stinger 1977 e Zerba

${ }^{12}$ P. Boehner e E. Gilson 1970: 133. 
existência de uma problemática cética, caraterística de um contexto de crise e conflito de doutrinas, e a recepção dos filósofos céticos não são excludentes. Ao contrário, a existência deste contexto ressalta a relevância dos textos dos céticos e faz com que sejam lidos à luz dessa problemática. Foi o que ocorreu no Helenismo caracteristicamente entre os apologistas e os pensadores da patrística. Isso se deu, sobretudo, mas não exclusivamente, no período anterior ao Concílio de Nicéia (325). Este concílio acabou por determinar uma doutrina ortodoxa por decreto imperial, o que nem de longe significou um efetivo consenso entre as várias correntes da época. É nesse sentido que a controvérsia não foi superada pela via teórica ou argumentativa, mas teve tão somente uma solução política.

É no contexto do início da Modernidade que se pode falar do ceticismo fideísta, que embora ausente da filosofia cética antiga deve ser visto como consequência das críticas céticas às faculdades da razão, abrindo caminho assim para a experiência transcendente da fé, enquanto a razão seria limitada em sua capacidade de estabelecer, ou ao menos de alcançar, a certeza. Essa discussão já é encontrada no Helenismo nos primeiros três séculos do Cristianismo ${ }^{13}$.

Os argumentos céticos, sobretudo pirrônicos, tiveram um papel relevante neste momento histórico, portanto no período bastante conturbado e instável desta religião nascente, anterior ao Concílio de Nicéia e ao edito de Teodósio (380) que finalmente a estabeleceu como religião oficial do Império Romano. É sobretudo na obra dos apologistas que encontramos o recurso aos argumentos céticos, apontando para a diaphonia entre as doutrinas filosóficas gregas, com suas controvérsias insolúveis, embora nem sempre Acadêmicos e Pirrônicos sejam explicitamente citados, ou quando o são, sejam distinguidos claramente. O único caminho para o verdadeiro conhecimento é a fé, como superação dos limites da razão humana, caminho este inexistente para os filósofos da Antiguidade grega.

A principal fonte sobre essa discussão é a Praeparatio Evangelica (principalmente livro XV) de Eusébio de Cesarea (início do século IV), que se tornou inclusive, por este motivo, uma fonte importante de doxografia de filósofos céticos, destacando-se os tropos de Enesidemo ${ }^{14}$. Em suas três principais obras Praeparatio Evangelica, Demonstratio Evangelica e Historia Ecclesiae, Eusébio apresenta sua versão dos dois primeiros séculos do Cristianismo e expõe o pensamento dos apologistas, os primeiros a defenderem a religião nascente. As obras de Eusébio, destacando-se a Praeparatio Evangelica, traduzida no século XV pelo humanista de origem bizantina Gregório de Trebizonda, tiveram um grande impacto no Humanismo moderno e estão na base das questões de Budé no De transitu Hellenismi ad Christianismum ${ }^{15}$.

\footnotetext{
13 Brown 1971: 49-95.

${ }^{14}$ Eusébio discute explicitamente a diaphonia e a époche, Barnes 1990:7.

${ }^{15}$ Stinger 1977.
} 
É aparentemente nos apologistas, em Clemente de Alexandria (150-215) e posteriormente em Gregório Nazianzeno (329-390), que encontramos a origem do conceito de Helenismo tal como discutido por Budé16. O Helenismo representa assim um dos mais importantes momentos históricos do que se convencionou denominar de um ponto de vista sociológico e antropológico de "transferência cultural". Podemos entender deste modo a passagem do pensamento filosófico grego para o pensamento cristão com a consequente formação nos séculos seguintes de uma cultura híbrida no contexto do mundo europeu ocidental, integrando elementos do pensamento greco-romano, do Judaísmo e do Cristianismo. O que se constata nesse contexto é que o recurso pelo Cristianismo à filosofia grega no caminho aberto por Fílon de Alexandria, o filósofo judaico do séc. I a.C. que primeiro aproxima a tradição mosaica da platônica e da estóica, é irreversível e tampouco pode ser delimitado em uma leitura seletiva apenas pelas caraterísticas e interesses do próprio Cristianismo.

Os apologistas dos séculos II e III empregaram argumentos procurando defender a superioridade do Cristianismo sobre a filosofia grega, mostrando como esta vive mergulhada em controvérsias, e apresenta uma pluralidade de doutrinas em confronto e inconciliáveis, portanto em uma diaphonia anepicriton na expressão usada pelos céticos, um conflito sem critério de solução. É curioso notar a preocupação dos apologistas não apenas em mostrar a inferioridade da religião (por exemplo, o Orfismo) e dos mitos gregos, mas sobretudo da filosofia grega. Isso pode ser devido a formulações pelos platônicos, aristotélicos, estóicos e epicuristas já no contexto do Helenismo de concepções de sophia, ou seja sabedoria em sentido positivo e prático e não apenas de filosofia, enquanto busca do saber ou da verdade. Esta sophia não tem uma pretensão apenas epistêmica, explicativa, ou seja, científica, mas formula sobretudo uma ética prática, constituindo um modo de viver, estabelecendo uma ética com regras do bem viver, com pretensão de levar à tranquilidade e à felicidade. Um dos grande exemplos disso são as Meditaçôes de Marco Aurélio (121-180), de inspiração estóica. É principalmente sob esse aspecto que a filosofia grega pode ser vista como rival do Cristianismo. E é nesse sentido também que a nova religião se apresenta como fundada na fé e na revelação divina, que a tornam superior, e não apenas nas opiniões e nas doutrinas humanas, ou seja, em uma razão limitada por natureza e sujeita a inúmeras controvérsias insolúveis. Portanto, a discordância entre os filósofos é evidência da fragilidade de suas teorias e dos limites da razão argumentativa diante da fé e da revelação, único caminho capaz de levar à certeza e à verdade.

Esse momento histórico é de importância crucial porque o Cristianismo ainda não se tornara uma religião de estado, fato talvez inédito, ao menos no

16 "Heleno" era o termo utilizado em sentido amplo neste período para designar os nãocristãos ou pagãos. (Chadwick 1993: 152). 
mundo ocidental e do Oriente Médio. Sua institucionalização e a preservação de sua unidade dependiam do estabelecimento de uma ortodoxia, isto é, de uma doutrina aceita como correta.

Mas, este é o paradoxo. A crítica referente à controvérsia insolúvel e estéril lançada pelos apologistas contra os filósofos gregos afinal pode ser aplicada igualmente às diferentes seitas do Cristianismo dos primeiros séculos, o período ante-nicênico. O Concílio de Nicéia tampouco conseguiu estabelecer a pretendida homogeneidade da doutrina cristã, o que de um ponto de vista histórico jamais foi alcançado. As controvérsias entre as seitas, as heresias, ou diferentes "escolhas" (sentido literal de hairesis) não foram menos acirradas do que entre os filósofos gregos, ao contrário, levaram mesmo a perseguições e tentativas de supressão raramente encontradas no contexto filosófico (Mansfeld, 1988).

Apesar de episódios como a condenação de Sócrates, a expulsão de Platão de Siracusa e o suicídio de Sêneca, resultados de confrontos políticos, na Grécia Antiga as controvérsias e as disputas entre os filósofos eram consideradas parte de sua atividade.

Alguns dos apologistas chegaram mesmo a atribuir as controvérsias no âmbito do Cristianismo à permanência da influência da filosofia grega no pensamento religioso, remontando à Fílon de Alexandria, que efetivamente primeiro estabeleceu essa ponte. Isso teria influenciado por sua vez decisivamente o Cristianismo a partir de pensadores como São Justino Mártir, filósofo de formação e também os primeiros representantes da patrística na escola neoplatônica cristã de Alexandria, Clemente e Orígenes. O recurso aos conceitos filosóficos gregos na formulação de teses teológicas teria introduzido inevitavelmente essas controvérsias no próprio Cristianismo.

Questões filosóficas penetraram assim o pensamento religioso que em seu desenvolvimento institucional e no combate às heresias tornou-se altamente dogmático. Ao introduzir a diaphonia entre correntes filosóficas para apontar as limitações da razão, a discussão teológica acaba mostrando como essa diaphonia ocorre entre as próprias doutrinas religiosas e interpretações concorrentes das Sagradas Escrituras.

Podemos considerar, portanto, que a crise teológica que Popkin identifica no início da modernidade e que exemplifica pela controvérsia entre Erasmo e Lutero e que Budé vê como uma ameaça ao Cristianismo tem um precedente significativo nas controvérsias dos primeiros séculos do Cristianismo. Tampouco nesse momento houve solução teórica, mas apenas uma solução política através do Concílio de Nicéia, que mesmo assim não produziu o consenso esperado uma vez que muitos líderes cristãos não se submeteram a suas resoluções e foram declarados hereges.

Quando se dá uma transferência cultural, a cultura de que se apropria nunca é apropriada de forma homogênea, sem conflitos interpretativos e a leitura feita, por mais seletiva que seja, não impede que traços críticos de um pensamento 
contaminem o outro como efetivamente aconteceu no Cristianismo dos primeiros séculos e no início do Renascimento, mais uma vez com a retomada do pensamento grego, sobretudo da filosofia cética.

A ambiguidade se encontra portanto no fato de que o pensamento cristão recorre à filosofia grega em suas várias correntes para o estabelecimento da doutrina ortodoxa, e esta a origem da teologia, mas ao mesmo tempo deve reiterar sua superioridade sobre este pensamento de modo a superá-lo, recorrendo para isso à fé e à revelação. De um ponto de vista institucional, contudo, a fé e a revelação são insuficientes enquanto fundamentos da doutrina. Embora a doutrina reafirme essa superioridade, isso deve ser feito recorrendo a conceitos e argumentos tomados de empréstimo aos filósofos gregos em uma defesa argumentativa do que a revelação proclama.

É exatamente esse contexto de controvérsia que Guillaume Budé, conhecedor dos apologistas, ao menos através de sua leitura de Eusébio de Cesarea, vê ser retomado no Humanismo Renascentista. Vê assim o que Popkin (op. cit.) denominou de "crise intelectual da Reforma" como até certo ponto reproduzindo as controvérsias do início do Cristianismo. Os textos clássicos cuja leitura se difunde nessa época trazem mais lenha para a fogueira de uma crise institucional que já sacudia a Igreja desde o século XIV e que se radicaliza irremediavelmente nos séculos XV e XVI. É como se ele próprio, enquanto influente humanista no reinado de Francisco I tivesse contribuído diretamente para introduzir a "serpente no paraíso".

Inicialmente admirador da filosofia cética, recomendando mesmo que seja seguida contra a "arrogância de nosso pensamento", Budé muda posteriormente de posição ${ }^{17}$. Passa a reiterar assim, tal como os primeiros apologistas, a superioridade do Cristianismo sobre os clássicos, recorrendo a formulações inusitadas como, "se os filósofos tem a razão nós temos o oráculo". É curiosa a referência à fé e à revelação como "oráculo", expressão que parece deslocada ao ser aplicada ao Cristianismo. Porém, esta palavra latina, derivada de orare, falar, e equivalente ao grego logion, diminutivo de logos, era também empregada no sentido de "revelação" e de "palavra divina". É encontrada em traduções de textos do Antigo e Novo Testamento, tendo uso corrente nesta época. Além disso, pode tratar-se também de uma referência ao oráculo da Sibila de Cumas e à misteriosa profecia contida na IVa. Écloga de Virgílio, que antecipa a vinda de Cristo, citação que se encontra no apologista Justino Mártir e é retomada ao longo da tradição medieval e Renascentista ${ }^{18}$.

"Mas, na verdade, nossa filosofia, filha do Cristianismo, é totalmente oposta e hostil à filosofia estóica e arrogante, que paga tributo e recorre à sabedoria

\footnotetext{
${ }^{17}$ Floridi 2002: 36 e McNeil 1975: 127.

${ }^{18}$ Bourne 1916.
} 
humana. Nossa filosofia que se fundamenta sobre um oráculo (oraculari autoritate condocefacta) considera que o homem - por mais excelente e feliz que seja sua natureza, tão sábio e sapiente quanto é - não possui, ao menos quando se trata de alcançar o soberano bem, nenhum suporte ou proteção ao recorrer ao conjunto de seus sentidos nem aos recursos de seu espírito". (Budé, op. cit.: 96)

Portanto o elo entre os primeiros séculos do Cristianismo ainda não institucionalizado e o contexto do século XVI quando essa institucionalização sofre sua crise mais grave é mais forte do que a interpretação que aqueles que minimizam a controvérsia religiosa e o sentido de fideísmo como Caujolle-Jaslawski (op. cit.), Giocanti (op. cit.) e Naya (op. cit.) parecem admitir. E sua importância para o ressurgimento do ceticismo é por sua vez particularmente relevante tendo em vista ser esta corrente filosófica grega por excelência que enfatiza o conflito insolúvel e o problema do critério e fornece os argumentos que alimentam essa controvérsia - essa dynamis antithétike, de acordo com a terminologia cética.

A análise comparativa entre as controvérsias encontradas no contexto do surgimento do Cristianismo e a crise intelectual da Reforma a que Popkin se refere mostra assim que na verdade o contexto do século XVI tem um antecedente importante no Helenismo.

Pode-se dizer, portanto, que não é apenas a retomada dos céticos antigos no contexto do Humanismo Renascentista e sua recepção, fiel ou não a estes filósofos, na controvérsia da Reforma e da Contra-Reforma que traz uma contribuição fundamental a esse debate e à eventual formulação de um ceticismo fideísta no sentido de anti-intelectualista. Mas, o uso que os apologistas e a patrística do início do Cristianismo fizeram dos filósofos gregos, inclusive Acadêmicos e Pirrônicos, também se constitui em uma fonte importante de argumentos para essa controvérsia, que teria tido um antecedente nesse período histórico do início do Cristianismo.

Nem o apelo à filosofia grega, nem a rejeição da filosofia grega e o apelo à fé garantiram a almejada unidade doutrinária do Cristianismo nem no Helenismo, nem na Modernidade, talvez porque a principal lição da filosofia cética seja que a experiência humana é plural e diversificada e qualquer tentativa de reduzi-la a uma unidade dará origem a uma diaphonia anepicriton. 


\section{Bibliografia}

Annas, J. e Barnes, J. (1985), The Modes of Scepticism: Ancient Texts and their Modern Interpretation. Cambridge.

Barnes, J. (1990), The Toils of Scepticism, Cambridge.

Bayle, P. (1994), "Pirro" em Dictionnaire historique et critique, in O que nos faz pensar 8: 62-65.

Bourne, E. (1916), “The Messianic Prophecy in Virgil's fourth eclogue”, CJ 11: 7, 390-400.

Blackwell, C. (1993), "Diogenes Laertius's "Life of Pyrrho" and the interpretation of ancient scepticism in the history of philosophy - Stanley through Bruckner to Tennemann", in R. Popkin e A. Vanderjagt (eds.) Scepticism and Irreligion in the Seventeenth and Eighteenth Centuries. Leiden, 324336.

Boehner, P. e E. Gilson (1970), História da Filosofia Cristã. Petrópolis.

Brown, P. (1971), The World of Late Antiquity AD 150-750. London.

Budé, G. (1993), De transitu Hellenismi ad Christiasmum Libri tres. Paris.

Burnyeat, M. (ed.) (1983), The Skeptical Tradition. Los Angeles \& Berkeley.

Caujolle-Zaslawsky, F. (1977): "L'interprétation du scepticisme comme philosophie du doute religieux: analyse d'un malentendu", Revue de Théologie et de Philosophie 27.2: 81-111.

Chadwick, H. (1993), The Early Church. London.

Cicero (1976), Academica. Oxford.

Floridi, L. (2002), Sextus Empiricus: the Transmission and Recovery of Pyrrhonism. New York.

Giocanti, S. (1998) "Histoire du fidéisme, histoire du scepticisme?" Revue de Synthèse 119: 93-110 [http://download.springer.com/static/pdf/457/ art\%253A10.1007\%252FBF03181378.pdf?auth66=1420500389_3d3f1e abcb38f8ad427208b750b5aa3f\&ext=.pdf em 20/11/2014]

Hall, E. T. (1976), Beyond Culture. New York.

Kristeller, P. O. (1979), Renaissance Thought and its Sources. New York.

Laércio, Diógenes (1989), Vida e doutrina dos filósofos ilustres. Brasília.

Mansfeld, J. (1988), "Philosophy in the service of Scripture", in J. M. Dillon e A. A. Long (eds.), The Question of Eclecticism: Studies in Later Greek Philosophy. Berkeley \& Los Angeles. [http://publishing.cdlib.org/ ucpressebooks/view?docId=ft029002rv\&chunk.id=d0e3936\&toc. depth=1\&toc.id=d0e3936\&brand=ucpress em 04/01/2015]

Marcus Aurelius (1930), Meditations. Oxford. 
McNeil D. O. (1975), Guillaume Budé and Humanism in the Reign of Francis I. Genebra.

Montaigne, M. de (1962), Apologie de Raimond Sebond. Paris.

Naya, E. (2009), "Renaissant Pyrrhonism: a relative phenomenon ", in G. Paganini e J. R Maia Neto (eds.), Renaissance Scepticisms. Springer, 15-32.

Popkin, R. H. (2003) The History of Skepticism from Savonarola to Bayle. Oxford.

Sextus Empiricus, (1979), Works. Oxford.

Skinner, Q. 2002, "Moral ambiguity and the Renaissance art of eloquence", in Visions of Politics, vol. II. Cambridge, cap.10.

Skinner, Q. (1997), Reason and Rhetoric in the Philosophy of Hobbes. Cambridge.

Stinger, C. L. (1977), Humanism and the Church Fathers: Ambrogio Traversari and Christian Antiquity in Italian Renaissance. New York.

Winter, E. (ed.) (2005), Discourse on Free Will: Erasmus and Luther. New York.

Zerba, M. (2012), Doubt and Skepticism in Antiquity and the Renaissance. Cambridge. 